\title{
KEBERLANJUTAN TRANSPORTASI DI KOTA SURABAYA MELALUI PENGEMBANGAN KAWASAN BERBASIS TOD (Transit Oriented Development)
}

\author{
Adopting TOD (Transit Oriented Development)for Sustainable \\ Transportation in Surabaya City
}

\section{Ketut Dewi Martha Erli Handayeni ${ }^{1}$ dan Putu Gde Ariastita}

Diterima : 12 November 2013

Disetujui: 25 April 2014

\begin{abstract}
Abstrak: Rencana pengembangan monorail dan tramway di Kota Surabaya memberi konsekuensi pada penetapan pergerakan berbasis transit.Konsep TOD (Transit Oriented Development) bertujuan untuk mendorong penggunaan moda transit melalui pengembangan kawasan sekitar titik transit.Hasil studi di dunia menunjukkan keberhasilan TOD dalam mendorong penggunaan moda transit melalui intervensi penggunaan lahan sekitar titik transit.Oleh karena itu, perlunya upaya pengembangan kawasan berbasis TOD guna mewujudkan transportasi yang berkelanjutan. Upaya yang dapat dilakukan adalah melalui pengembangan kriteria kawasan berbasis TOD di kawasan transit, yaitu dengan karakteristik penggunaan lahan bercampur, intensitas kegiatan tingg, desain sirkulasi dan jaringan jalan yang terintegrasi dan desain kawasan yang ramah bagi pejalan kaki/pesepeda.
\end{abstract}

Kata kunci: keberlanjutan transportasi, TOD, transit

\begin{abstract}
Development plan of monorail and tramway in Surabaya City aimed to encourage the movement based transit. TOD (Transit Oriented Development) is model for integration of transportation and land use in order to encourage the transit ridership. The result of study in worldwide show the success of TOD application in increasing the usage of transit mode by developing policies on land uses around station/terminal. Therefore, it needs to adopt TOD in transit area of Surabaya City to achieve the sustainable transportation. This study conclude criteria of TOD that can be applied in transit area of Surabaya City are mixed land uses, high intensity of activities around station/terminal, integrated design of circulation and road network, and pedestrians/cyclists friendly design.
\end{abstract}

Keyword: TOD, transit oriented, sustainable transportation

\section{Pendahuluan}

Persoalan kemacetan kota di Surabaya disebabkan oleh tingginya penggunaan kendaraan pribadi pada ruas-ruas jalan utama kota. Persoalan kemacetan di Kota Surabaya dapat diidentifikasi dari kinerja jaringan jalan yang menunjukkan kemampuan kapasitas

\footnotetext{
${ }^{1}$ Jurusan Perencanaan Wilayah dan Kota, Institut Teknologi Sepuluh Nopember Kampus ITS Sukolilo, Surabaya 60111
} 
jalan dalam menampung volume kendaraan yang melintasi jalan tersebut, disebut sebagai istilah DS (Degree of Saturation) atau derajat kejenuhan. Beberapa ruas jalan Kota Surabaya menunjukkan DS yang melebihi 0,5 bahkan 0,8 yang berarti kinerja jalan sangat buruk atau menunjukkan persoalan kemacetan. Beberapa ruas jalan yang dimaksud antara lain Jalan Urip Sumoharjo (DS $=0,63$ ), Jalan Raya Darmo ( $D S=0,85)$, Jalan Banyu Urip $(1,32)$ dan beberapa ruas jalan lainnya (Master Plan Transportasi Surabaya 2017, tahun 2007). Beberapa ruas jalan utama kota ini menunjukkan tingkat volume lalu lintas yang cukup tinggi dan mendekati ukuran kapasitas jalan seharusnya. Oleh karena itu, adanya rencana pengembangan angkutan umum massal cepat (monorail dan trem) di Kota Surabaya bertujuan untuk mengatasi kemacetan dengan harapan adanya pengalihan penggunaan moda pribadi ke angkutan publik/umum, khususnya di beberapa ruas jalan utama kota yang menunjukkan kemacetan.

Upaya mengatasi kemacetan ini adalah dengan direncanakannya pengembangan angkutan umum massal cepat berbasis monorail dan tremway pada tahun 2013. Pengembangan angkutan umum ini menuntut perubahan perilaku berkendara dari penggunaan kendaraan pribadi ke angkutan publik/umum. Hasil studi di dunia menunjukkan bahwa pengalihan pengggunaan kendaraan ke angkutan publik/umum dipengaruhi oleh desain kawasan di sekitar lokasi transit (Sung dan Oh, 2012; The City of Calgary, 2004). Artinya, perlu integrasi perencanaan kawasan di sekitar lokasi transit dengan perencanaan jaringan (network) dan sarana transportasi yang akan dikembangkan. Pendekatan TOD merupakan konsep yang mengedepankan integrasi antara ciri kawasan di sekitar titik transit dengan sistem jaringan transit yang menghubungkannya, sehingga dapat mendorong penggunaan sistem transit (transit ridership) dan mengurangi penggunaan kendaraan pribadi. Oleh karena itu, perlu diperhatikan bagaimana pengembangan kawasan berbasis TOD yang dapat mempengaruhi perubahan perilaku berkendara untuk mengatasi kemacetan kota.

Keberhasilan konsep TOD di dunia dalam mengatasi kemacetan kota dapat menjadi lesson learned dalam mengatasi kemacetan di Kota Surabaya. Adanya kebijakan yang mengarahkan pergerakan berbasis transit melalui pengembangan angkutan umum massal (monorail dan tremwway) maka perlu diperhatikan ciri kawasan sekitar transit yang dapat mempengaruhi perubahan perilaku berkendara dari moda pribadi ke angkutan publik/umum. Penelitian mengenai kosep TOD di Indonesia masih sangat jarang dilakukan. Penelitian yang sudah berkembang sebelumnya hanya terbatas pada pembahasan bagaimana potensi penerapan TOD di kota-kota di Indonesia. Oleh karena itu, penelitian ini dikembangkan secara spesifik berkaitan dengan kriteria pengembangan kawasan di sekitar titik transit berbasis TOD yang dapat mendorong penggunaan angkutan umum massal sehingga terwujud keberlanjutan transportasi di Kota Surabaya.

\section{Metode Penelitian}

Perumusan kriteria kawasan berbasis TOD dilakukan dengan cara merumuskan long list (daftar panjang) indikator kawasan yang berbasis TOD melalui studi literatur mengenai best practice TOD di kota-kota di dunia. Perumusan long list ini dilakukan dengan teknik analisis deskriptif kualitatif melalui pendekatan teoritik mengenai konsep TOD.Melalui perumusan long list ini kemudian dilakukan konfirmasi terhadap kesesuaian indikator konsep TOD tersebut untuk diadaptasi pada konteks Surabaya.Konfirmasi ini dilakukan melalui pendekatan opini stakeholder-stakeholder kunci yang memahami karakteristik kawasan dan transportasi Kota Surabaya.Adapun teknik konfirmasi yang dilakukan adalah melalui pendekatan Delphi.Metode analisis Delphi merupakan analisis kualitatif yang mengutamakan peran ahli di dalamnya.Selanjutnya, perumusan kriteria-kriteria kawasan berbasis TOD diperoleh dari metode analisis komparatif deskriptif antara kondisi eksisting 
kawasan dengan indikator TOD yang telah dirumuskan dari kajian literatur dan analisis Delphi.

\section{Hasil dan Pembahasan}

Dalam merumuskan kriteria kawasan berbasis TOD di Kota Surabaya dilakukan dua tahap analisis.Pertama, analisis Delphi mengenai perumusan indikator TOD yang relevan diterapkan di Kota Surabaya.Kedua, analisis komparatif deskriptif yang menunjukkan hasil perbandingan teori dan analisis Delphi mengenai indikator TOD dengan kondisi eksisting kawasan sekitar transit.

\section{Perumusan Indikator TOD}

Pada perumusan indikator ini menggunakan pendekatan analisis Delphi yang melibatkan berbagai stakeholder. Stakeholder yang dimaksud adalah dari kalangan pemerintah dan akademisi yang memiliki kompetensi di bidang perencanaan kota dan perencanaan transportasi. Penelusuran opini stakeholder mengenai indikator TOD dilakukan pada sejumlah stakeholder terkait.Hasil perumusan indikator ini dapat dilihat seperti pada tabel 1 berikut.

Tabel 1 Analisis Delphi mengenai Persepsi Stakeholder terhadap Indikator TOD

\begin{tabular}{|c|c|c|c|c|c|c|}
\hline No. & Indikator TOD & & intah & & emisi & Alasan \\
\hline & & $S$ & TS & $S$ & TS & \\
\hline 1. & $\begin{array}{lr}\begin{array}{l}\text { Penggunaan } \\
\text { bercampur }\end{array} & \text { lahan } \\
\text { land uses) } & \end{array}$ & $\mathrm{v}$ & & $\mathrm{v}$ & & $\begin{array}{l}\text { Semakin bercampur ciri guna lahan suatu } \\
\text { kawasan maka akan semakin mendorong } \\
\text { penggunaan moda transit atau moda non- } \\
\text { motorized (berjalan kaki/bersepeda). Tingkat } \\
\text { guna lahan yang bercampur menunjukkan } \\
\text { tingkat keragaman penggunaan lahan. }\end{array}$ \\
\hline 2. & $\begin{array}{lr}\text { Tingkat } & \text { kepadatan } \\
\text { kawasan } & \text { sekitar } \\
\text { transit } & \end{array}$ & & $\mathrm{v}$ & & $\mathrm{v}$ & $\begin{array}{l}\text { Tingkat kepadatan sama halnya dengan } \\
\text { indikator tingkat intensitas kegiatan. Cukup } \\
\text { indikator tingkat kepadatan ditunjukkan oleh } \\
\text { indikator tingkat intensitas. Pada kawasan yang } \\
\text { perlu menjadi perhatian adalah tingkat } \\
\text { intensitas pemanfaatan ruang kawasan, } \\
\text { daripada tingkat kepadatan penduduk kawasan }\end{array}$ \\
\hline 3. & $\begin{array}{l}\text { Tingkat } \\
\text { kegiatan } \\
\text { transit }\end{array}$ & $\mathrm{v}$ & & $\mathrm{v}$ & & $\begin{array}{l}\text { Menunjukkan tingkat intensitas pemanfaatan } \\
\text { ruang kawasan. Semakin tinggi tingkat } \\
\text { intensitasnya maka konsentrasi } \\
\text { kegiatan/aktivitas di dalam kawasan semakin } \\
\text { tinggi pula. Hal ini berpotensi untuk } \\
\text { mendorong penggunaan moda transit sekitar } \\
\text { kawasan dengan intensitas kegiatan tinggi }\end{array}$ \\
\hline 4. & $\begin{array}{l}\text { Desain sirkulasi dan } \\
\text { jaringan jalan menuju } \\
\text { lokasi transit }\end{array}$ & $\mathrm{v}$ & & $\mathrm{v}$ & & $\begin{array}{l}\text { Semakin baik desain sirkulasi dan jaringan jalan } \\
\text { yang menghubungkan kawasan menuju lokasi } \\
\text { transit, maka tingkat penggunaan moda transit } \\
\text { akan semakin tinggi }\end{array}$ \\
\hline 5. & $\begin{array}{l}\text { Desain kawasan yang } \\
\text { ramah bagi pejalan } \\
\text { kaki/pesepada }\end{array}$ & $\mathrm{v}$ & & $\mathrm{v}$ & & $\begin{array}{l}\text { Untuk mengurangi penggunana kendaraan } \\
\text { pribadi dan meningkatkan penggunaan moda } \\
\text { transit, maka perlu didukung oleh fasilitas- } \\
\text { fasilitas pejalan kaki di dalam kawasan. } \\
\text { Semakin baik dukungan fasilitas, maka akan } \\
\text { mendorong penggunaan moda transit. }\end{array}$ \\
\hline 6. & $\begin{array}{l}\text { Adanya fasilitas Park } \\
\text { and Ride }\end{array}$ & & $\mathrm{v}$ & & $\mathrm{v}$ & $\begin{array}{l}\text { Fasilitas ini diperlukan namun untuk jangka } \\
\text { pendek masih belum urgent untuk } \\
\text { dikembangkan dalam mendorong moda transit. } \\
\text { Namun perlu dipertimbangkan pada desain } \\
\text { kawasan. }\end{array}$ \\
\hline
\end{tabular}




\begin{tabular}{|c|c|c|c|c|}
\hline \multirow[t]{2}{*}{ No. } & \multirow[t]{2}{*}{ Indikator TOD } & Pemerintah & Akademisi & \multirow[t]{2}{*}{ Alasan } \\
\hline & & $S \quad T S$ & $\mathrm{~S} \quad \mathrm{TS}$ & \\
\hline 7. & $\begin{array}{l}\text { Tingkat perfomansi } \\
\text { moda transit }\end{array}$ & $\mathrm{v}$ & $\mathrm{v}$ & $\begin{array}{l}\text { Semakin baik tingkat performansi moda transit } \\
\text { maka semakin rendah penggunaan moda } \\
\text { pribadi. Indikator ini penting, namun tidak } \\
\text { berkaitan langsung dengan karakteristik } \\
\text { kawasan secara fisik. Hal ini dapat } \\
\text { dipertimbangkan dalam mendukung kawasan } \\
\text { berbasis TOD. }\end{array}$ \\
\hline
\end{tabular}

Sumber: hasil analisis, 2013

Berdasarkan hasil analisis Delphi, dapat disimpulkan bahwa indikator TOD yang relevan diterapkan di Kota Surabaya adalah berkaitan dengan:

1. Penggunaan lahan bercampur (Mixed land uses)

2. Tingkat intensitas kegiatan sekitar transit

3. Desain sirkulasi dan jaringan jalan menuju lokasi transit

4. Desain kawasan yang ramah bagi pejalan kaki/pesepada

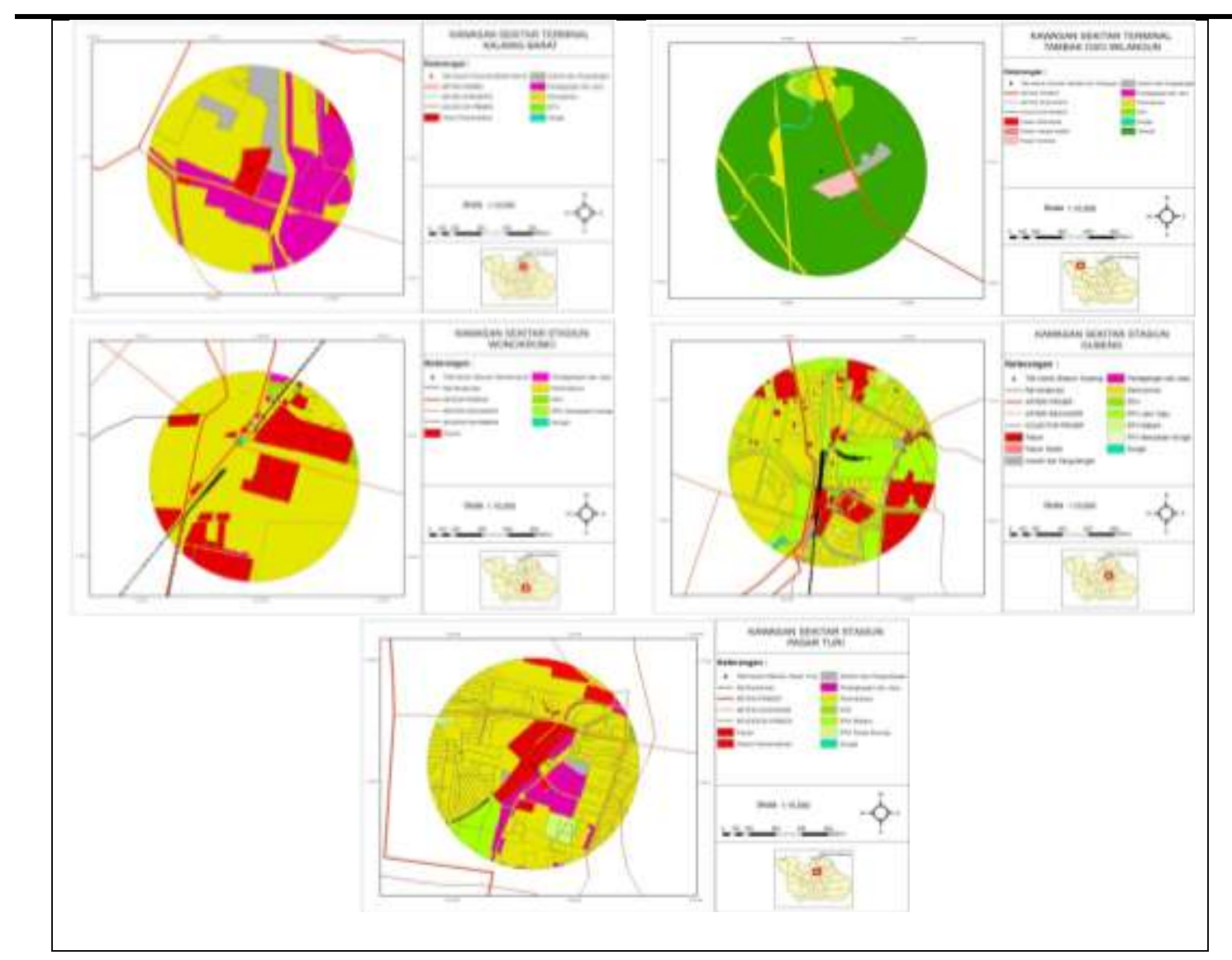

Gambar 1 Peta Penggunaan Lahan Pada Masing-masing Kawasan Transit

\section{Komparasi Kondisi Eksisting Kawasan Sekitar Transit dengan Indikator TOD}

Dalam menentukan kriteria-kriteria kawasan berbasis TOD yang relevan dalam mendukung keberlanjutan transportasi di Kota Surabaya, maka komparasi kondisi eksisting terhadap indiaktor TOD dilihat berdasarkan keempat indikator yang telah dirumuskan pada 
analisis Delphi.Adapun hasil komparasi kondisi tersebut dapat dilihat seperti pada tabel berikut.

Tabel 2Analisis Komparasi Kondisi Eksisting Kawasan Transit berdasarkan Indikator Penggunaan Lahan

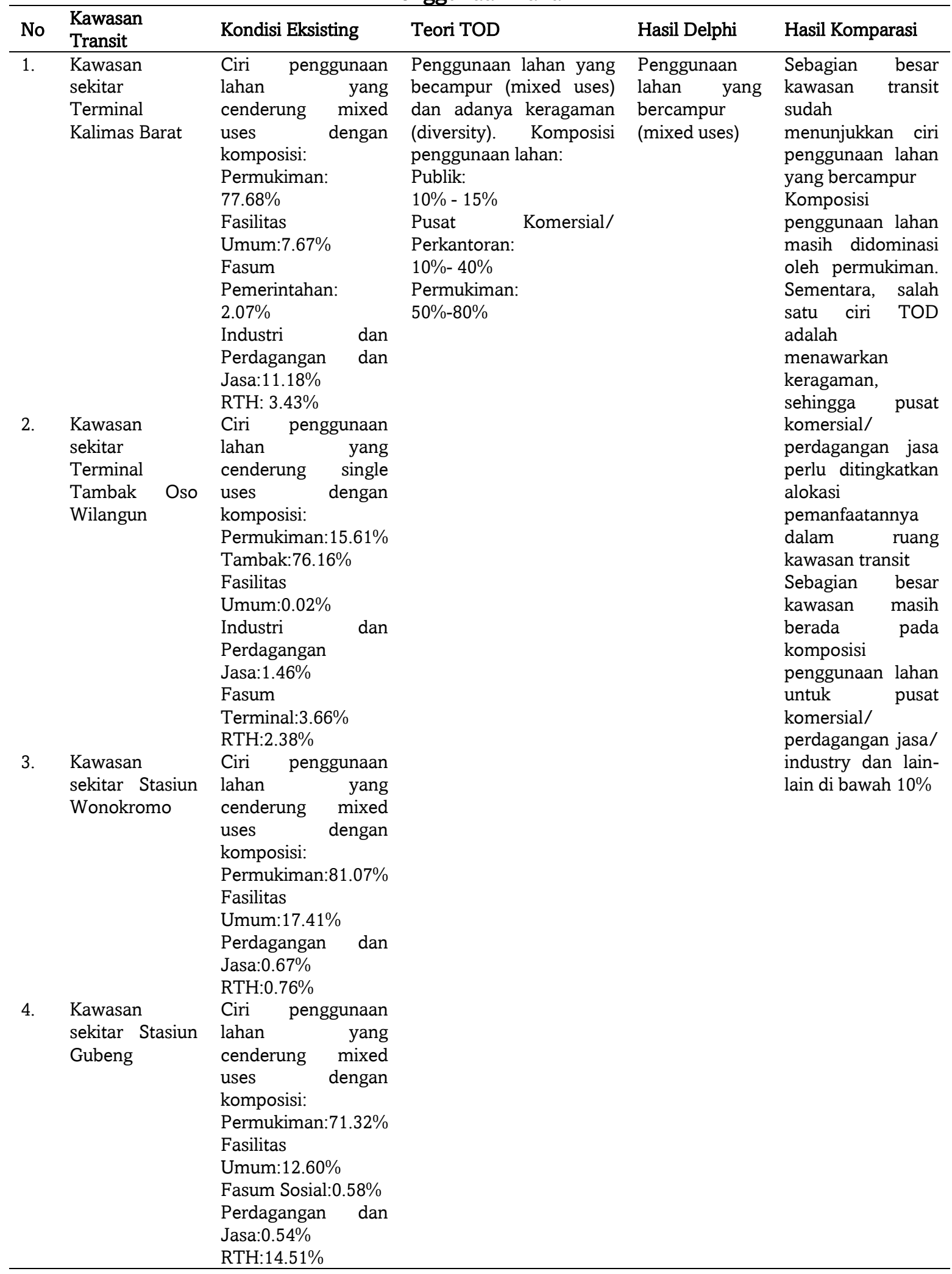




\begin{tabular}{|c|c|c|c|c|c|}
\hline No & $\begin{array}{l}\text { Kawasan } \\
\text { Transit } \\
\end{array}$ & Kondisi Eksisting & Teori TOD & Hasil Delphi & Hasil Komparasi \\
\hline 5. & $\begin{array}{l}\text { Kawasan } \\
\text { sekitar Stasiun } \\
\text { Pasar Turi }\end{array}$ & $\begin{array}{lr}\text { Ciri } & \text { penggunaan } \\
\text { lahan } & \text { yang } \\
\text { cenderung } & \text { single } \\
\text { uses } & \text { dengan } \\
\text { komposisi: } & \\
\text { Permukiman:77.68\% } \\
\text { Fasilitas } \\
\text { Umum:7.67\% } \\
\text { Fasum } \\
\text { Pemerintahan:2.07\% } \\
\text { Industri } & \text { dan } \\
\text { Perdagangan } & \text { dan } \\
\text { Jasa:11.18\% } & \\
\text { RTH:3.43\% } & \end{array}$ & & & \\
\hline
\end{tabular}

Berdasarkan hasil komparasi indikator penggunaan lahan, dapat diketahui bahwa sebagian besar kawasan transit sudah menunjukkan ciri penggunaan lahan yang bercampur.Hal ini dapat dilihat dari peta penggunaan lahan dari masing-masing kawasan transit pada gambar 1 berikut.Namun, komposisi penggunaan lahan untuk pusat komersial/perkantoran perlu ditingkatkan alokasi pemanfaatan ruangnya dalam kawasan sekitar transit dengan persentase minimal 10\% dari luas kawasan transit.

Selanjutnya, analisis komparasi mengenai indikator intensitas kegiatan dilihat dari tingkat KDB dan KLB pada masing-masing kawasan transit.Hasil analisis ini dapat dilihat pada tabel 3 berikut. Berdasarkan hasil komparasi indikator intensitas penggunaan lahan, dapat diketahui bahwa sebagian besar kawasan menunjukkan intensitas KDB yang tinggi, namun KLB rendah.Artinya intensitas bangunan memiliki kepadatan secara horizontal daripada vertikal.Dalam mengupayakan kawasan transit berbasis TOD maka perlu diarahkan KLB minimal pada kategori menengah, atau delapan kalinya dari nilai KDB.

Tabel 3 Analisis Komparasi Kondisi Eksisting Kawasan Transit berdasarkan Indikator Desain Sirkulasi dan Jaringan Jalan

\begin{tabular}{|c|c|c|c|c|c|}
\hline No & $\begin{array}{l}\text { Kawasan } \\
\text { Transit }\end{array}$ & $\begin{array}{l}\text { Kondisi } \\
\text { Eksisting }\end{array}$ & Teori TOD & Hasil Delphi & Hasil Komparasi \\
\hline 1. & $\begin{array}{l}\text { Kawasan } \\
\text { sekitar } \\
\text { Terminal } \\
\text { Kalimas } \\
\text { Barat }\end{array}$ & $\begin{array}{lr}\text { Lokasi } & \text { transit } \\
\text { berada } & \text { pada } \\
\text { jaringan } & \text { jalan } \\
\text { kolektor } & \end{array}$ & $\begin{array}{l}\text { Lokasi transit sebaiknya tidak } \\
\text { berada pada jaringan jalan arteri, } \\
\text { serta dihubungkan oleh sejumlah } \\
\text { akses menuju lokasi transit seperti } \\
\text { pada gambar berikut: }\end{array}$ & \multirow{5}{*}{$\begin{array}{l}\text { Jaringan jalan } \\
\text { yang baik } \\
\text { menghubungkan } \\
\text { kawasan dengan } \\
\text { lokasi transit } \\
\text { dapat } \\
\text { mendorong } \\
\text { penggunaan } \\
\text { moda transit }\end{array}$} & \multirow{5}{*}{ 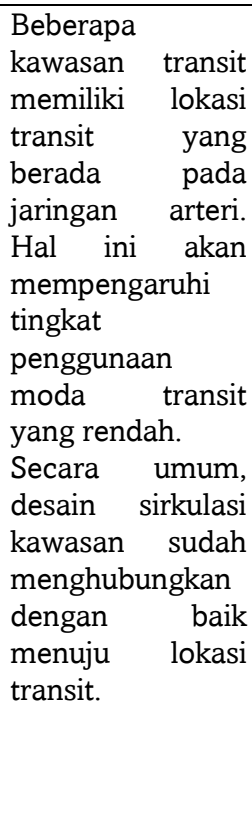 } \\
\hline 2. & $\begin{array}{l}\text { Kawasan } \\
\text { sekitar } \\
\text { Terminal } \\
\text { Tambak Oso } \\
\text { Wilangun }\end{array}$ & $\begin{array}{lr}\text { Lokasi } & \text { transit } \\
\text { berada } & \text { pada } \\
\text { jaringan } & \text { jalan } \\
\text { arteri } & \end{array}$ & 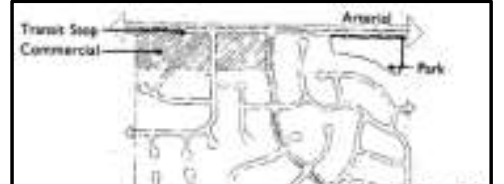 & & \\
\hline 3. & $\begin{array}{l}\text { Kawasan } \\
\text { sekitar } \\
\text { Stasiun } \\
\text { Wonokromo }\end{array}$ & $\begin{array}{lr}\text { Lokasi } & \text { transir } \\
\text { berada } & \text { pada } \\
\text { jaringan } & \text { jalan } \\
\text { arteri } & \end{array}$ & consens & & \\
\hline 4. & $\begin{array}{l}\text { Kawasan } \\
\text { sekitar } \\
\text { Stasiun } \\
\text { Gubeng }\end{array}$ & $\begin{array}{l}\text { Lokasi } \\
\text { berada } \\
\text { jaringan } \\
\text { kolektor }\end{array}$ & $\operatorname{Tinax}_{\sin }$ & & \\
\hline 5. & $\begin{array}{l}\text { Kawasan } \\
\text { sekitar } \\
\text { Stasiun } \\
\text { Pasar Turi }\end{array}$ & $\begin{array}{l}\text { Lokasi transit } \\
\text { berada pada } \\
\text { jaringan jalan } \\
\text { kolektor }\end{array}$ & pкssesized & & \\
\hline
\end{tabular}


Berdasarkan hasil komparasi indikator desain sirkulasi dan jaringan jalan menunjukkan bahwa sebagian besar kawasan transit telah memiliki jarringan jalan yang menghubungkan kawasan dengan lokasi transit.Sementara, beberapa lokasi transit masih berada pada jaringan jalan arteri yang dapat mempengaruhi tingkat penggunaan moda transit.. Selanjutnya analisis mengenai komparasi indikator desain kawasan yang ramah bagi pejalan kaki menunjukkan sejauhmana tingkat kemudahan kawasan dijangkau dengan berjalan kaki/bersepeda dari lokasi transit menuju bangunan-bangunan di dalam kawasan.Pada tabel 4 menunjukkan hasil komparasi tersebut. Secara umum, kawasan transit di Kota Surabaya belum menunjukkan desain kawasan yang ramah bagi pejalan kaki/pesepeda.Hal ini berkaitan dengan persoalan jumlah fasilitas yang belum memadai, kualitas fasilitas yang masih kurang, serta jaringan pejalan kaki yang belum terintegrasi dengan baik dengan bangunan-bangunan yang ada di dalam kawasan.

Tabel 4 Analisis Komparasi Kondisi Eksisting Kawasan Transit berdasarkan Indikator Desain Kawasan Pedestrian Friendly

\begin{tabular}{|c|c|c|c|c|c|}
\hline No & $\begin{array}{l}\text { Kawasan } \\
\text { Transit }\end{array}$ & Kondisi Eksisting & Teori TOD & Hasil Delphi & Hasil Komparasi \\
\hline 1. & $\begin{array}{l}\text { Kawasan } \\
\text { sekitar } \\
\text { Terminal } \\
\text { Kalimas } \\
\text { Barat }\end{array}$ & $\begin{array}{lr}\text { Minimnya } & \text { fasilitas } \\
\text { pejalan kaki } & \text { dengan } \\
\text { kualitas yang } & \text { belum } \\
\text { memadai } & \end{array}$ & $\begin{array}{lr}\text { Desain } & \\
\text { kawasan } & \text { yang } \\
\text { ramah } & \text { bagi } \\
\text { pejalan } & \text { kaki. } \\
\text { Jarak } & \text { antar }\end{array}$ & $\begin{array}{l}\text { Perlunya } \\
\text { fasilitas pejalan } \\
\text { kaki yang } \\
\text { memadai untuk } \\
\text { menghubungkan }\end{array}$ & $\begin{array}{l}\text { Secara umum, } \\
\text { kawasan transit } \\
\text { di Kota Surabaya } \\
\text { belum } \\
\text { sepenuhnya }\end{array}$ \\
\hline 2. & $\begin{array}{l}\text { Kawasan } \\
\text { sekitar } \\
\text { Terminal } \\
\text { Tambak } \\
\text { Oso } \\
\text { Wilangun }\end{array}$ & $\begin{array}{lr}\text { Minimnya } & \text { fasilitas } \\
\text { pejalan kaki di } & \text { sekitar } \\
\text { kawasan } & \text { dengan } \\
\text { kualitas yang buruk }\end{array}$ & $\begin{array}{l}\text { bangunan yang } \\
\text { memadai untuk } \\
\text { dijangkau } \\
\text { dengan } \\
\text { berjalan kaki }\end{array}$ & $\begin{array}{lr}\text { lokasi } & \text { transit } \\
\text { dengan } & \text { lokasi } \\
\text { tujuan di } & \text { dalam } \\
\text { kawasan } & \end{array}$ & \begin{tabular}{lr}
\multicolumn{2}{l}{ mencirikan } \\
kondisi & desain \\
kawasan & yang \\
ramah & bagi \\
pejalan & \\
kaki/pesepeda.
\end{tabular} \\
\hline 3. & $\begin{array}{l}\text { Kawasan } \\
\text { sekitar } \\
\text { Stasiun } \\
\text { Wonokromo }\end{array}$ & $\begin{array}{lr}\text { Adanya fasilitas pejalan } \\
\text { kaki yang cukup } \\
\text { memadai, } \\
\text { kualitasnya } \\
\text { kurang }\end{array}$ & & & $\begin{array}{l}\text { Persoalan utama } \\
\text { adalah kualitas, } \\
\text { kuantitas dan } \\
\text { disintegrasi } \\
\text { jaringan pejalan }\end{array}$ \\
\hline 4. & $\begin{array}{l}\text { Kawasan } \\
\text { sekitar } \\
\text { Stasiun } \\
\text { Gubeng }\end{array}$ & $\begin{array}{l}\text { Fasilitas pejalan kaki } \\
\text { sekitar kawasan cukup } \\
\text { baik, namun belum } \\
\text { menjangkau selurh } \\
\text { kawasan transit secara } \\
\text { terintegrasi }\end{array}$ & & & kaki. \\
\hline 5. & $\begin{array}{l}\text { Kawasan } \\
\text { sekitar } \\
\text { Stasiun } \\
\text { Pasar Turi }\end{array}$ & $\begin{array}{l}\text { Tidak adanya fasilitas } \\
\text { pejalan kaki di lokasi } \\
\text { transit, di beberapa } \\
\text { area sekitar transit } \\
\text { sudah tersedia fasilitas } \\
\text { pejalan kaki namun } \\
\text { kualitasnya masih } \\
\text { belum memadai dan } \\
\text { belum terintegrasi }\end{array}$ & & & \\
\hline
\end{tabular}

\section{Kesimpulan}

Secara teotitik, konsep TOD menjanjikan adanya keberlanjutan transportasi suatu kota dengan mengintegrasikan jaringan transportasi terhadap sebaran kota. Bentuk integrasi ini diwujudkan dari pemusatan kegiatan dan pembangunan di kawasan sekitar transit. Artinya, konsentrasi kegiatan di sekitar transit akan mendorong penggunaan moda 
transit, sehingga perlahan dapat mengurangi ketergantungan terhadap moda pribadi. Konsep TOD ini sangat potensial diterapkan di Kota Surabaya yang ditunjukkan dari adanya kedekatan pusat kegiatan kota dengan titik transit (terminal dan stasiun). Adapun kawasan transit tersebut adalah kawasan sekitar Terminal Kalimas Barat, kawasan sekitar Terminal Tambak Oso Wilangun, kawasan sekitar Stasiun Wonokromo, kawasan sekitar Stasiun Pasar Turi, dan kawasan sekitar Stasiun Gubeng. Kelima kawasan transit ini sudah menunjukkan konsentrasi kegiatan di sekitar stasiun/terminal. Namun, penggunaan moda transit (kereta dan angkutan kota) masih relatif rendah. Dalam upaya mendorong penggunaan moda transit di Kota Surabaya maka perlu dikembangkan kawasan transit berbasis TOD dengan kriteria sebagai berikut:

1. Penggunaan lahan bercampur di kawasan transit dengan komposisi penggunaan lahan untuk pusat komersial / perkantoran lebih dari 10\% dari total luas kawasan transit

2. Peningkatan intensitas kegiatan di kawasan transit dengan KDB lebih dari $75 \%$ dan KLB minimal $600 \%$

3. Pengembangan desain sirkulasi yang menghubungkan semua jalan dengan lokasi transit serta lokasi transit minimal berada pada jaringan jalan kolektor

4. Desain kawasan transit yang menyediakan fasilitas pejalan kaki/pesepeda yang memadai dengan penyediaan jaringan pejalan kaki yang terintegrasi dengan bangunan.

\section{Daftar Pustaka}

Lin, J.J and C.C. Gau, 2006, A TOD planning model to review the regulation of allowable development densities around subway stations, Land Use Policy, Vol.23, pp.353 - 360

Loo, Becy P.Y, Cynthia Chen, Eric T.H. Chan, 2010, Rail-based transit-oriented development: Lessons from New York City and Hong Kong, Landscape and Urban Planning, Vol.97 (2010), pp.202-212

$\mathrm{Mu}$, Rui dan Martin de Jong, 2012, Establishing The Conditions For Effective Transit-Oriented Development In China: The Case Of Dalian, Journal of Transport Geogr aphy

Olaru, Doina, Brett Smith, and John H.E Taplin, 2011, Residential location and transit-oriented development in a new rail corridor, Transportation Research Part A, Vol.45, pp.219-237

Renne, John L., 2008, Smart Growth and Transit-Oriented Development at the State Level: Lessons from California, New Jersey, and Western Australia, Journal of Public Transportation, Vol. 11, No.3, pp.77108

Sung, Hyungun and Ju-Taek Oh, 2011, Transit-oriented development in a high-density city: Identifying its association with transit ridership in Seoul, Korea, Cities, Vol.28, pp.70-82

The City of Calgary Land Use Planning and Policy, 2004, TOD Best Practice Handbook

Watson et al, 2003, Time-Saver Standards, USA: The McGraw-Hill Companies, Inc 